DOI: $\underline{10.20472 / T E .2018 .6 .1 .006 ~}$

\title{
PRINCIPALS' LEADERSHIP IN HIGH PERFORMANCE SCHOOLS IN NORWAY
}

\section{OLE PETTER VESTHEIM}

\begin{abstract}
:
Inspired by the theory of practice architectures (Kemmis et al., 2014), a theory concerning what practices consist of and are shaped by, this article seeks to examine school leadership as practice in high performance schools in Norway. Through interviews with principals at seven case schools, I examine what these principals cite as central in their leadership practices. A central goal for the study was to investigate and understand how leadership as practice was made possible through practice architectures. The result of the analysis led to three distinct categories: leadership as facilitating learning, leadership as building relationships and leadership as assessment of practice. Further, the study shows how these leadership practices are ecologically depended on each other.
\end{abstract}

\section{Keywords:}

Educational leadership, principal, school development, practice, practice architectures, qualitative research, interviews

JEL Classification: 120,129

\section{Authors:}

OLE PETTER VESTHEIM, Nord University, Norway, Email: ole.p.vestheim@nord.no

\section{Citation:}

OLE PETTER VESTHEIM (2018). Principals' leadership in high performance schools in Norway. International Journal of Teaching and Education, Vol. VI(1), pp. 85-102., 10.20472/TE.2018.6.1.006 


\section{Introduction}

A sentral goal in this study was to examine school leadership as practice in high performing schools in Norway. Further, it was important to investigate and understand how how school leadership as practice was made possible through practice architectures. In Norway, the principal has the ultimate responsibility for their school's activities, ranging from economic management to educational practice. The government White Paper, No. 31 (2007-2008) Quality in Education states that school leadership is significant for the learning environment, and that school leadership progressively has become more demanding and complex in the last decades (Kunnskapsdepartementet, 2008). Decentralization, accountability for pupil performance, implementation of new reforms and new approaches for learning are some of the reasons that school leadership has evolved in this way (Olson, 2008). This increased focus on the principal's significance for the school's practice, has led to more explicit expectations and requirements from the Norwegian Directorate for Education and Training (The Norwegian Directorate of Education and Training, 2016).

The expectations for locally managed schools provide principals with significant influence, and the authority to make decisions that have implications on the quality of teaching and learning as well as the school's capacity for development and improvement (Furlong, 2013). School leaders' decisions, strategies and leadership practices affect the quality of the education being offered and how teachers behave in the classroom when meeting their pupils (Bush, 2008; Steyn \& Du Plessis, 2007). With this backdrop, the article addresses the following, both empirical and theoretical research question: What leadership practices characterize principals in schools that over time have achieved high results in national tests and how can these practices be understood through the theory of practice architectures?

\section{Contextualization of national tests}

The introduction of national tests in the three basic skills of reading, mathematics and English may be seen as part of the development in the educational sector. Results from the tests should contribute to educational development on one hand, while on the other act as an indicator of the extent to which the school may be considered to have achieved the desired results. School leaders relate to national tests in different ways, but in most cases the results of the tests are used to analyse one's own school, and then used in making comparisons to other schools (Elstad, 2009). The analyses often results in external and internal causal explanations for the results, using the school's pupil base, parental involvement, pupil's former schools, former teachers' work or the school's practice in general to explain both weak and strong results, (Seland, Vibe, \& Hovdhaugen, 2013). Moreover, research shows that what are regarded as weak results on the national tests can lead to feelings of guilt and reactions of grief among the staff in the school (Seland et al., 2013), which may be thought of as a result of the perspective of accountability. Research on leadership practices in schools that achieve excellent results shows that the principals of these schools manage to prevent such 
feelings by taking responsibility for the burden and supporting their employees in situations where they are exposed to external pressures of accountability for results. Leaders also are sensitive to how teachers might perceive these pressures, and find ways to keep motivation levels high and limit cynicism levels (Leithwood, Steinbach, \& Jantzi, 2002). A study conducted by Elstad (2009) shows that principals change practice to satisfy results and goals set by the school owners. In particular, this applies to schools in municipalities where the test results are used as a means for accountability with direct incentives in different ways. "Teaching to the test" was a central strategy to achieve the results that were set (Elstad, 2009, p. 184).

Vestheim and Lyngsnes (2016) shed light on how national tests affect practices and are used as a tool in school development at schools that over time have achieved good results on the tests. The results from the tests were used as a tool for self-evaluation and development of understanding of the basic skills. Vestheim (2014) found in a study of teachers' interpretation of their own classroom practice in similar schools that teachers cite clear leadership as one of the reasons that the school achieves these results. This means that such teachers see, among other things, that the principals are clear on which direction the school is going, and that they facilitate and expect commitment from the staff.

\section{Previous research on leadership in high performance schools: a short review}

Several studies have documented that principals, through their leadership are of great significance to pupils' learning (DuFour \& Marzano, 2011; Hitt \& Tucker, 2016; Leithwood, Harris, \& Hopkins, 2008; Møller, 2009; Møller et al., 2005; Viviane M. J. Robinson, 2007; Timperley, 2011). Historically, it has been claimed that a principal's practice has an indirect effect on pupils' learning (Hitt \& Tucker, 2016). However, as the understanding of the role of the principal has been expanded, the opposite has been found to be true, in that principals' practices have direct consequences for pupils' learning (Day, Gu, \& Sammons, 2016). Fullan (2014) writes that principals are the second most important factor for pupil learning after the teacher. Principals' practices in schools that achieve good results create a learning environment that facilitates opportunities and the sharing of experiences among employees, and for the development of pupils' academic and social outcomes (Blase \& Blase, 2003; Fullan, 2014; Møller et al., 2005).

In a review article Hitt and Tucker (2016) directed the spotlight on the type of leadership practices that have positive significance for pupil's attainment of academic learning. They developed five general areas they considered to be overlapping in the material they were based on: a) establishing and conveying the vision, (b) facilitating a highquality learning experience for pupils, (c) building professional capacity, (d) creating a supportive organization for learning, and (e) connecting with external partners. In addition to these areas, twenty-eight more specific areas were identified. The findings mirror the complexity linked to the practice of the role of principal and how practices of the school and principal relate to both internal and external conditions. Through 
facilitating a structure and culture for the school's development and contributing to a positive school environment, principals promote pupils' motivation, commitment and skills (Day et al., 2016).

On the basis of many studies on school leadership, Fullan (2014) outlines three principles which are the central characteristics in the leadership practices. First, he claims that principals must be leaders for learning or the leader who plays on the team with appropriate others in their schools' context. The principal's role is thus not to control their employees through a hierarchical leadership, but through leading their teachers side by side in processes that are intended to improve practice. The second principle is based on the fact that principals must be a system player. This includes making use of all the resources available both inside and outside the school in order to build professional capital. The purpose of this is to create a culture and practice of continuous learning where the principal has a key role. The third and final principle is called an agent of change. An overall goal is constantly to build professional capital (Hargreaves \& Fullan, 2012), that is, to develop collective learning in the staff.

Many studies point to the fact that principals who successfully achieve good academic results set clear goals and have high expectations for the school as a whole (Day et al., 2016; Hitt \& Tucker, 2016; V. M. J. Robinson, Lloyd, \& Rowe, 2008; Vestheim, 2014), and that these are adapted to the contextual conditions where the school is located (Hitt \& Tucker, 2016; Leithwood et al., 2008). Pashiardis, Savvides, Lytra, and Angelidou (2011) support this, finding that principals at schools in areas with lower socio-economic status set different goals and have other expectations than principals at schools which are located in areas with higher socio-economic status.

From Norwegian research into leadership in successful schools, we find, for example, Møller et al. (2005) who studied leadership in respected schools in Norway. They found that among other things cooperation and team effort in combination with a learningcentred approach in the school's philosophy and practice were important elements for success. A learning centred approach was understood as a focus on constantly being able to be improved. The study also shows that the schools' principals have a respect for each individual pupil and the employees through building a professional community in which all have responsibility for the school's development.

Emstad (2011) describes leadership practices where the principal is involved at all levels in the school in order to form a basis for further work after an evaluation process. This happened through facilitating reflection and knowledge sharing among the staff. When the whole school worked together on goal setting for further work after completing the evaluation, it was easier for the principal to legitimize the decisions about development and improvement of teaching. There may be reason to believe that the similar findings Emstad (2011) refers to can also apply when using national tests as a tool for evaluation.

In Norway there is not a long tradition of research into effective or good schools. One of the reasons may be that historically no indicators of quality have been found that 
are similar to national tests. There are also few studies that illuminate leadership practices in schools that have achieved good results on national tests in Norway despite the fact that the tests are considered an important indicator of the school's quality.

\section{The theoretical framework of the study}

The approach to the term practice as it is used in this article is holistic and builds on the theory of practice architecture (see Kemmis et al., 2014). Practice such as Kemmis et al. (2014) describe it is made up of sayings, doings and relatings that hang together in a characteristic project.

Practice is a type of cooperative human activity that takes place through actions and activities that become comprehensible under various conditions of the relevant ideas related to the discourses. These are distributed among the people and the objects that are involved in the context through time and place. For example, work-related practices are comprised by the sayings, doings and relatings that have been made possible through practice architectures. Actors who engage in the practices reproduce not only earlier understandings and actions, but in addition they develop new knowledge through a tangled cooperation with structures and actions. Practices, both individual and collective, form and are formed by practice architecture (Kemmis \& Grootenboer, 2008; Kemmis et al., 2014). The practice architectures are the preconditions that make practices possible, and hold them in place. Among other things, practices architectures consist of various combinations of dimensions described thus:

- Cultural-discursive arrangements are the resources that make possible the language and discourses used in and about this practice.

- Material-economic arrangements are the resources that make possible the activities undertaken in the course of the practice.

- Social-political arrangements are the resources that make possible the relationship between people and non-human objects that occur in the practice (Kemmis et al., 2014).

In the theory of practice architecture, practices occur because people act collectively, not alone. Individual understandings and actions are orchestrated through collective social-relational projects. Such projects may include teaching pupils to read or to develop the school as an organization. Both individual and collective participation in practices are shaped by the practice architecture that characterizes the practice through the cultural-discursive, material-economic and social-political events (Kemmis et al., 2014). On this basis it could be argued that school leadership could be considered as a practice that shapes and is shaped by the surrounding arrangements of the practice architecture. On the one hand, the practices are understood as the sayings, doings and relatings expressed in and through leadership practice. Sayings can be understood as the thoughts and concepts that are expressed. Doings may be 
seen as what people both do and say they do, while relatings are about how the actors in practice relate to other actors, for example, through power and solidarity. On the other hand, leadership practice is understood in light of that part of the practice architecture that is comprised to the cultural-discursive, material-economic and socialpolitical events which characterize the site.

This way of understanding leadership emerges as consistent with theories of practice and practice architecture that emphasize the dynamic and interaction between the individual, the social and the arrangements that form the framework in order to make practices possible. Wilkinson and Kemmis (2015) point out an important distinction between studying distributed leadership and leadership as a practice. While in distributed leadership one focuses on how participants in a practice relate to each other (Spillane, Halverson, \& Diamond, 2004), in practice theory one investigates the reciprocal relationships between the practices themselves. The reciprocated relationships between practices are referred to as "ecologies of practices" (Kemmis et al., 2014, p. 43). Kemmis, Wilkinson, Hardy, and Edwards-Groves (2009) describe ecologies of practices as distinctive, interconnected webs of social activities (characteristic arrangements of sayings, doings and relatings) that are mutuallynecessary to order and sustain a practice as a practice of a particular kind and complexity. This means that leading by its nature, in this study, has to be ecologically arranged to other educational practices.

\section{Methodology}

The focus is directed towards leadership practices from the perspective of the principals. In their exercise of leadership, this practice will be understood in the study's theoretical framework both as an individual practice and as a practice that is only made possible through other practices in the site. In order to study leadership practices in the selected schools, the principals have been interviewed through qualitative single interviews, which are suitable for obtaining information about how principals think about, learn about, experience and understand themselves and their actions in the context of which they are a part (Kvale \& Brinkmann, 2009). The interview guides were semi-structured and built around several themes that were considered key areas within the education sector in Norway in general, as well as matters relating to national tests in particular. In addition, conducted group interviews with teachers and pupils at the respective schools, open observations of teaching situations and the granting of access to the school's assortment of plans and documents have been utilized. It is likely that this will affect and have a bearing on the analysis and the results as presented in the article. The triangulation method has provided a richer basis for understanding the leadership practices in the case schools, and has served as a separate supplement in the analysis work even though the sources have not been directly used in the article.

\section{Sampling}

The selection of appropriate schools to study has been of a strategic sampling (Patton, 2002), meaning that the schools have been selected on the basis of appropriate 
criteria. The first criterion used as a basis for selection was the requirement that the schools had to have achieved good results in national tests over a minimum of three years. A statistical analysis was performed where the relationship between the schools' results over the last three years was higher than could be expected on the basis of income and education levels in the municipalities (Langfeldt, 2015). A second criterion was that schools' participation in the study was voluntary, and that they agreed to participate in the research project. The selection consisted of seven schools from four counties and six municipalities. Four of the schools were joint primary and lower secondary schools (years 1-10), two were primary schools (years 1-7) and one a lower secondary school (years 8-10). This selection resulted in interviews with seven principals who were responsible for medium sized schools, by Norwegian standards. The smallest school had approximately 120 pupils and the largest had about 320 pupils. The schools had between 14-26 teachers depending on the number of pupils in the school. At two of the schools, the deputy principal was also interviewed.

\section{Analysis}

The qualitative interviews were recorded on an audio recorder and later transcribed into written form. Each interview $(\mathrm{N}=7)$ had a duration of approximately 60 minutes. Interviews were conducted by at least two researchers who were linked to various parts of the research with different intentions and goals. The analysis was begun along the way and closely followed by the interviews through discussion and interpretation among the researchers. By means of such discussions about possible interpretations, the researchers have attempted to meet the requirement of communicative validity (Kvale \& Brinkmann, 2009). The results presented in this article are constructed on the background of my subjective selection and interpretations of the empirical data, which can result in misinterpretations. However, on several occasions I have met the informants at seminars organized by Learning Regions at which I have presented preliminary findings from the study. In this connection representatives from the relevant schools could present feedback on the interpretations and the results I presented. In this way, a form of "member-check" has been carried out, which can contribute to strengthening the study's validity (Creswell, 2007; Lincoln \& Guba, 1985).

Analyses are performed with a constant comparative analysis method (Corbin \& Strauss, 2008), which involves an inductive approach by starting from the empirical data to develop new theory. Starting with the transcribed interviews, I proceeded to read them and write code tags that I perceived as relevant in each interview. Next, I compared the tags from the individual interviews looking for patterns, similarities and differences between the interviews. The findings and results presented focus on the categories developed from the data material through the constant comparative analyse method (Boeije, 2002; Corbin \& Strauss, 2008). Data have been coding line-by-line and themes and categories have been emerged by constantly comparing data within same case, data between cases, codes with categories, and so on. Based on the words and key quotations that stood out in the encoding process I applied the following questions to the material: What is central to the principals' thinking about educational practice? What characterizes the principals' relationships with teachers, parents and 
other authorities in the school's sites? What do the principals see as their most important tasks? How do the principals relate to trends and guidance from the state and school owner? Together, these issues could contribute to an understanding of what characterizes the leadership practices of the principals. This process of analysis eventually resulted in three main categories; Leadership as facilitating learning, Leadership as building relationships and Leadership as assessing practice.

\title{
Findings: Dimensions in leadership practices
}

The categories that are presented here represent findings in the study. Nuances in the form of different dimensions and elements are presented through individual cases. It is acknowledged that practices are found in local sites and thus they will differ from school to school. Each of the category is considered a practice.

\section{Leadership as facilitating learning}

Leadership practices expressed through the empirical material show that facilitating learning is a central part of the principals' practices. This facilitating occurs in various ways and takes place at several levels in the schools. The following quote from one of the principals may represent a typical way of thinking among most of the principals who participated in the study:

\begin{abstract}
First, let it be said that I am not the one who provides learning. It is the teachers who provide learning for them [the pupils]. I make it possible for the teachers to learn. Then I'm thinking of facilitating, right? I think of it as fellowship, where we have to look out for the individuals and facilitate for them in relation to the skills teachers have and the resources we have available.
\end{abstract}

The quotation shows that the principals see it as their role to facilitate the resources available so they will be made use of in the best possible way. It is clear that the teachers are closest to the pupils and can contribute to their learning, while the principal's role is to create fellowship and direction. Another principal explains her practice in the following way:

\footnotetext{
I wanted to be a part of forming and determining how a school should operate. Quite clearly. I knew that was where I wanted to be, for there I could get something done. It's something about the openness that exists. I was looking for community, and I don't think that is easy to get in all schools. I have faith in communities. I don't believe in too much diversity among the teachers. But community that I usually speak about to the teachers, it is about going in the same direction, but knowing that we are on a wide path.
}

Another principal facilitates learning through being a motivator and creating attitudes. He creates the motivation and attitudes through being visible in the school environment, as he says: "You have no idea how important it is regarded by both pupils and teachers that the principal shows up in the classroom on a regular basis, by just wandering about. It may be somewhat cynical to say it, but it has an enormous effect when one gives some words of praise about what was going on in that lesson. Extremely important!" The same principal says:

What does it mean to be a teacher? What are the most important tasks a teacher has? There is in fact nothing new under the sun when it comes to pedagogy. There are many new words that have appeared, but the real things have changed little. How can I have an attitude to what is basic to being a teacher? In fact, it is not that much more than that you know how your pupils 
are doing it, and what you can do to help them. This has always been the teachers' task. It's about attitude. The leadership has an important job in terms of working with attitudes.

Several of the principals have clear expectations on behalf of the school, the teachers, the pupils and their guardians. These are expressed in various ways, but what emerges as most central is the practice that the principal creates through various forms of facilitating learning in the school as an organization. There is a consistent and substantial consensus among the principals that an important premise for development and learning is that they facilitate a culture among the staff where sharing, reflection, assessment and evaluation of existing practice are foundational elements. One principal explains this as follows:

It is important for me that we are referred to as a good school, and that people do not talk about good classes. Thus we have to share, and focus on the school as a unit, and not on individual teachers. We can never all be equally good at everything, but together we can be good. It's about being united on what we decide. About preparing a common understanding. We have joint discussions, share experiences, share expertise and share what we do. Previously, it was privately practicing teachers who sat with their plans. Now, I think we are going to ease the burden for those who will take over after us.

Another principal says:

We have steadily gathered teachers from the first to the tenth class in reflection groups. Then we reflect, as I call it, purposelessly; it is the dialogue that is most important. Listening to each other and reflecting on classroom practice. Recently the deputy principal has been great at collecting articles and research reports which they can read before we meet to discuss what consequences these may have for my practice, my habits, my approach to the pupils and learning.

The principals are facilitators for learning in different ways. The leadership practice that facilitates learning is linked to and belongs to a different kind of practice where the prominent category is leadership as relationship building.

\section{Leadership as relationship building}

Several of the principals cite the significance of building relationships between the school and other actors in the community as an important part of their practice. The relationships are built both towards the guardians, teachers, pupils, sports teams, companies, and others who in various ways contribute as supporters of the school. An argument for creating relationships between the school and other actors is to highlight the school's practices.

Relationship building between the school and guardians emerges as central to the practices of several of the principals. One principal tells of one school practice referred to as a parenting course:

On one such parenting course we took them up to our outdoor education area. We showed them the site, and engaged in activities that we can use for outdoor education. When we got back to the school we asked questions about the practice in relation to the curriculum and what the parents thought the children could learn from what they had done. When we talked about that, one parent confessed that he never would have accepted that his child should participate in outdoor education if he himself had not been able to participate in this session.

Another principal explains it this way: 
We have expectations of the parents, and they have expectations of us; and we follow up these expectations in everyday routines. It is about what is now called assessment for learning, for these words have come afterwards, even though is maybe something we have been doing for a long time. It's a lot about how to motivate and work with the individual in the normal day to day classroom, in cooperation with the home.

Several of the principals say that with the relationships in place, it is easier to raise issues with the parents, and vice versa, that it becomes easier for the parents to contact the school if there should be something they wanted to discuss. For one of the principals the relationship to the parent group is different, saying that:

Most of the parents are very satisfied. I like it when someone asks slightly different questions from what we do, but they [PTA] are often negative in terms of what we're up to. It feels as if they almost want to be deciding. They have not completely understood that they are an advisory body, I feel then. Most of the time it is I who meet them. But I feel that the cooperation between school and home at teacher level is working very well.

Another dimension in the principals' practices as relationship builders is their way of wanting close contact with the classroom and having an understanding of what is happening there. This relates to the desire for insight into conditions which deal with both the teachers' lessons and the pupils' learning. One principal puts it this way: "I want to be informed about what is happening in the classroom. Then I must have conversations with the teachers, participate in the work teachers do, try to be supportive in the classroom, take supply teacher classes or help in the teaching. Yes, I try to involve myself and take the responsibility I must in collaboration with others." The significance of relationships also arises in the way several of the principals facilitate meetings between the staff in the schools where dialogue and reflection have an important place. One principal says:

I believe in making shared time meaningful for the teachers. For them to experience that it is something that pertains to them and something that is important. We collaborate closely, sharing with each other, so that we know what the other is doing. As the principal I am the standardbearer, and then I have to be able to go with my head raised high in front of the column and say that this is the way we do it in our school.

Several of the principals talk about the significance of being available and collaborate with sports clubs, voluntary organizations and businesses with a view of creating a good environment for growing up in. A principal who took over a rural school with what he perceived as a poor learning environment tells this about how they worked at building relationships in the community:

\footnotetext{
We wanted to create a new culture in which the parents were on the side of the school in relation to having a vision for the future. In addition to meetings with the parents, we also had many meetings with teams and organizations with the idea that they should set the same limits for leisure time that we set for the school. The parents had to be on the school's side when it came to following up on their children, but also the pupils as a group.
}

A final category that is developed deals with how principals relate to changes and how they think about the school's development of the practice. The category presented below is leadership as assessment of practice. 


\section{Leadership as assessment of practice}

From the empirical data, this category stands out as a part that may reflect the principals' leadership practices. To consider the school's practice before adjustments are made is also expressed under the category facilitating for learning, which deals with how the principals work and use their position as a leader to work with other involved actors in the work of school development. Leadership as assessment of practice is understood for its part as being about what kind of practices provide the basis for changes being either accepted or rejected in the school as an organization. One of the principals, which represents multiple informants, states the following:

There is time allotted to educational development work one day a week, and I have told the staff that this is holy time. Then everyone has to be there, in order to lay the basis for the school's pedagogy. I control this time with a firm hand. I try to listen first, and thereafter it is I who decide. [...] Some trends you must accept. Such as what you are required to do, while other things, you can choose. We try not to run a "kangaroo school" as it is called. We try to do things because we think they are important.

The principal from one of the other schools says this about how the school relates to trends and development work:

We haven't been world champions in school development. We have avoided big pendulum fluctuations in extremes, but rather try to advance evenly. We have been a traditional school, relatively conservative, you could say. We have pushed through some traditional subjects as well, we may as well be honest and admit it. We have not been progressive.

The third principal says:

We are willing to change, but we are not always those who are the first to jump on board. We can accommodate what we want in relation to the waves that come, what fits our method of doing things, not going to the outer extremes of all the waves. We have to have faith in our own product and do not let ourselves be knocked over because someone says that we are not modern enough. We need to accept what is good, and we have done that.

One of the principals finds that it is hard to get to the development processes. She tells us that the school has strong personalities at every level, and that all the levels are run differently. Here is a statement she made:

It's like rowing against the wind. Or against a full storm (laughter). There are some teachers who think there should be more fixed time, and who wish they could have more hours at school. Now they are here from eight until the pupils can go home. But it is difficult. [...] So [in order to get the teachers on board] clear information, and that they see the usefulness of it. But it is a challenge, considering how little fixed time we have and with opposition among the staff.

For several of the principals, there is a pervasive practice that new trends and guiding principles are considered in relation to the existing practice. Some of the principals have this as a deliberate strategy, while for others, such as the last quoted principal, it can appear as if they relate hesitantly due to opposition from other staff members.

In the next section the categories will be discussed and set within a theoretical framework to illuminate how the practices can be understood in the light of leadership theory and as practices in a practice architecture. The results presented above are summarized in Figure 1, leadership practices. The figure is designed with a background in understanding of practice (Kemmis et al., 2014, p. 33) as described in 
the study's theoretical framework. Practices is understood as comprised of sayings, doings and relatings which in turn hold together in a project. Each of these leadership practices are considered to be ecologically arranged to one another and other educational practices in the practice arhitecures.

Figure 1: The figure contains a selection of words used by the principals that can be understood as connected to either sayings, doings or relatings. It illustrates further that practices are ecologycally depended on each other.

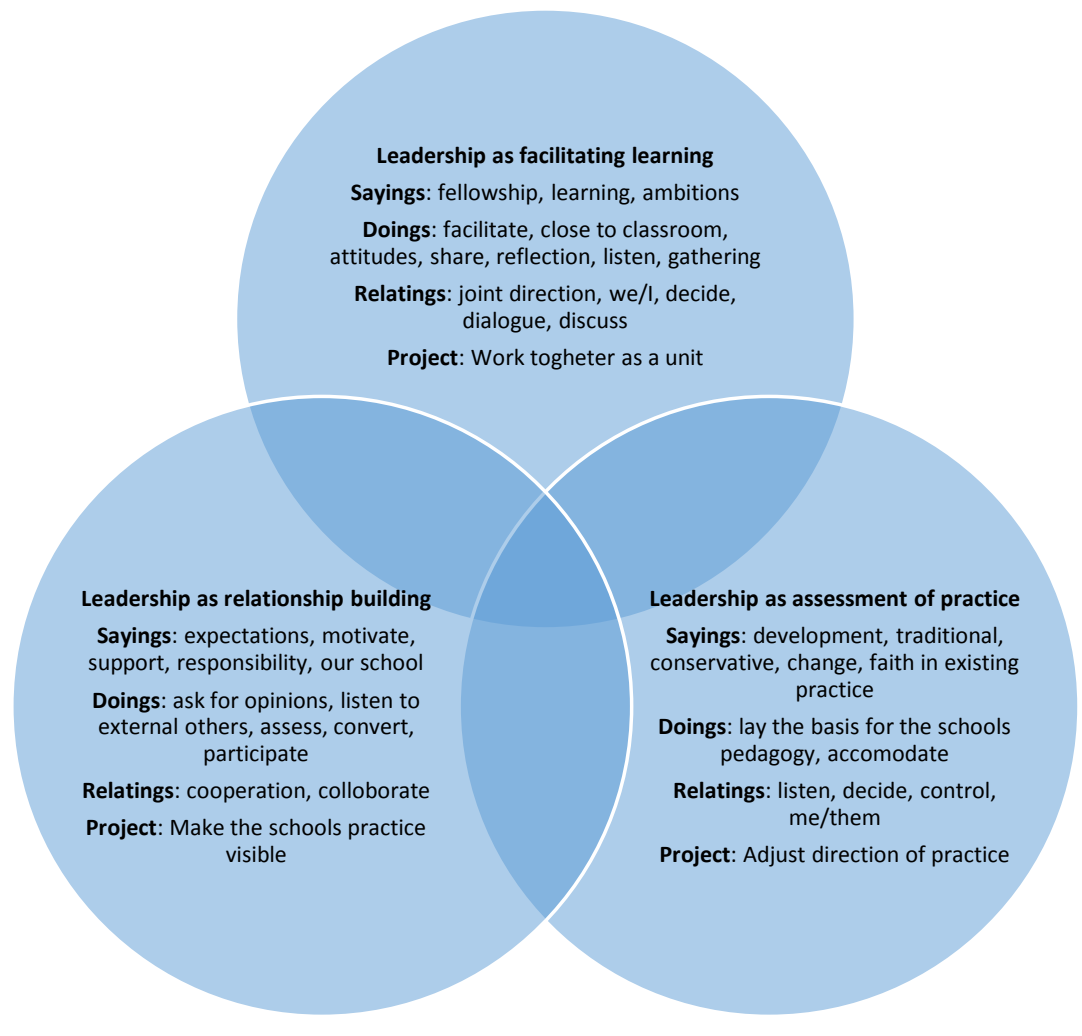

\section{Discussion}

The results from the study have several characteristics in common with what is described as effective leadership from previous research. The principals' practices involves many interest groups which in different ways contribute to the school's development. According to Hitt and Tucker (2016) successful principals manage to engage in and build relationships to others in order to develop practice. The leaders have high expectations of the people who in different ways are involved in the school, something which is pointed to as a central characteristic of leadership in schools that achieve good academic results (Viviane M. J. Robinson, 2007; V. M. J. Robinson et al., 2008). Overall the practices touch upon variables that are presented in corresponding quantitative studies. The purpose of this study is however to obtain qualitative dimensions in leadership practices. In the ongoing discussion, I would like, 
therefore, to show how leadership practices may be understood in relation to practice architectures (Kemmis et al., 2014; Wilkinson \& Kemmis, 2015).

Figure 1 shows how different words, phrases and actions are bunched together through practices that consist of sayings, doings and relatings which are connected to a project. Kemmis et al. (2014) argues that practices can be understood as sayings, doings and relatings which are distributed between people and the objects that are a part of the site where the practice take place. These three dimensions must be seen in relation to what the participants consider as their project. The project can be revealed through what the participants in the practice respond to with the question: what are you doing? (Kemmis et al., 2014, p. 39). Practices are sited and connected to both time and a place (Kemmis, 2009; Kemmis et al., 2014). This means that each leadership practices must be seen in the light of the site in which the principals find themselves in.

What do the principals say, what do they do (what do they say they do), what relationships do they have with other actors and what emerges as their project? I want to start with a last question first. The three categories presented in the article can be understood as practices among the principals that emerge as overriding in the study. The principals say that it is central to their practice to develop the school as an organization, thinking constantly of being able to improve the quality of what they are doing. This occurs through practices that are connected to both internal and external conditions in the school. The three categories can all be understood as sections of processes that are about a continual desire to make the school better than it is at present. The sayings, doings and relatings in one of the practices both shapes and are shaped by sayings, doings and relatings in the other practices. To be a facilitator of learning are inter-related to both the practice of building relationships and assessment of practice. This means that none of these practices would be the same if it existed in isolation from the other practices. According to the theory of practice architectures this can be understood as the ecologies of practices that suggests that all practices live and exists depending on other practices in the site (Kemmis et al., 2014, pp. 43-53). Further, I will elaborate how these practises are made possible through the practice architectures of the practises.

In the social-political dimension, two of the principals appear as hierarchy orchestrating through the way they speak about their relationships (relatings) to teachers. The following quotation gives an example of "I want more fixed time, but it is difficult. It's like rowing against the wind. Or like in a full storm. [...] But it is a challenge, considering how little fixed time we have and with the opposition among the staff." Another principal also states that: "Leadership is an important job in terms of working with attitudes". These quotations can be interpreted as showing that there is a distance and a hierarchical relationship between the principal and the teachers. They express the fact that teachers can be motivated to accomplish the job so that the aims are achieved if they as leaders are clear enough in their communication about what is expected. It may be argued that such an instrumental way of practising leadership ignores the fact 
that practices do not exist in a vacuum, but that they are part of a greater system of architectures that govern the practice (Kemmis et al., 2014). The other five principals explain it in a way that can be interpreted as more in line with several of the characteristics of being a leader of learning. Their leadership practices bear more signs of being relational (relatings) in the way they lead development through emphasizing to a greater degree inclusion of colleagues and other actors in the processes of practice development. Their leadership practices are based on discourses where the leaders desire development. The basis for this is best shaped through giving the teachers influence on how the development is going to occur, as this statement can illustrate: "... together we can be good. It's about being united on what we decide. About preparing a common understanding. We have joint discussions, share experiences, share expertise and share what we do". Despite the fact that leadership practices can be perceived as different, it may be claimed that all of the principals are working towards the same goal, indicating that different practices bring about the same results; good results in the national tests.

The social-political arrangements are expressed through power and solidarity and can be considered as resources that prevent or facilitate relationships (relating) between people in practices (Kemmis et al., 2014). This can be understood through the way the principals relate to, for example, trends in school development and education policy. The principals show solidarity in that they relate to trends and regulations but they also continue to exert their power in their leadership role with the school staff because they determine how much to integrate such trends. Like this principal states; "We are willing to change, but we are not always those who are the first to jump on board". It is worth noting how the principals consider existing practices in relation to new trends and currents which flow into the school. Partly, this solidarity is expressed towards new trends initiated by, for example, the school authorities, but the solidarity is restricted to an assessment of whether the "new" can contribute positively to the school's development. Hitt and Tucker (2016) show in their research that effective leaders not only focus on what needs to be improved, but that the practice is also characterized by the fact that they amplify and underpin what is seen to be done in a good way. The results of my study corroborate and further reinforce this finding since it emerges in the empirical material that this is a very important part of their practice. It also illustrates how local practices in a particular site inter-relate (Kemmis et al., 2014) with other educational practices.

In the social-political dimension of practice the principals take part of the teaching, visit the classrooms, and invite parents to discuss the schools practice. The purpose of this is bringing to light meanings and reflections that exists among people that are connected to the school. Practices that are played out derive their value through establishing belonging and solidarity among the people involved, through interactions and relationships that are regulated through power (Kemmis \& Smith, 2008). The study shows how the principals' leadership practices are regulated by the power that the leader has in a position as the overall leader. Among some of the principals the socialpolitical events can be understood as a power structure where the community and the 
involvement of other people and actors emerge also as key actors in developing the school. These other actors can be parents, local sports clubs and businesses, other schools as the principals themselves describe it. In other cases, we can see how relationships in the leadership practices are expressed through focus on creating motivation with other parties who are involved, by setting clear requirements and having high expectations for both individual teachers and the school as joint unit. In this way, both power and solidarity are expressed in various ways through practices and practice architectures (Kemmis et al., 2014).

In light of the cultural-discursive dimension (Kemmis et al., 2014) of practice, it interesting to notice the principals use of words. One principal uses for example "l" and "them", "resistance" and "headwind" in his position in relation to the teachers. The principal finds making time for pedagogical work and development difficult. Several of the other principals use words like "community", "sharing", "reflection" and "dialogue" about the work they are trying to facilitate in their respective schools. Such sayings may in turn help to contribute to create and manifest values as shared professional development and practice. In other words, the language used by the principals reflects their attitudes towards practice. As Wilkinson and Kemmis (2015) claim, practice architectures, such as here the cultural-discursive framework, will exist in a dialectical relationship with the practices for which they form the framework. Words and expressions (sayings) that the leader chooses will thereby both shape and be shaped by practice and the practice architectures.

The material-economic framework provides guidance for practices that are expressed through the leaders' actions (doings) (Wilkinson \& Kemmis, 2015). One such example might be how some of the principals assemble employees in a common place for dialogue and discussion. The place itself emerges as a physical arrangement that frames the practice. In addition, one hears how articles and current research reports are used as a starting point for these meetings, as this principal reports: "Recently the deputy principal has been great at collecting articles and research reports which they can read before we meet to discuss what consequences these may have for my practice, my habits, my approach to the pupils and learning". Without the media the practice would out of necessity present itself in a different way. This example shows how the practice of facilitating learning are connected to the practices of research and writing articles. The practice of facilitating learning are ecologically depended on other practices (Kemmis et al., 2014). The practice of using external material-economics can be understood as the headmaster wanting that the school should be developed through challenging the status quo.

\section{Conclusion}

By using practice architecture as a lens, we gain a picture of how practices are shaped by and shape practice architecture's cultural-discursive, material-economic and socialpolitical arrangements (Kemmis et al., 2014). The principals' practices both shape and are shaped by these surrounding structures. The findings and the theoretical framework tell us that different practice architectures produce different types of 
leadership practices. The practice architecture form the practices taking place and vice versa. It will be important for principals to be aware of how practices are shaped by and shape the frameworks for practice.

Leadership practices is about leading with support of the schools prevailing site conditions. The principals acknowledges that the school's development of practices can be enhanced by operating collectively in the site that the school is a part of.

\section{References}

Blase, J., \& Blase, J. (2003). Handbook of instructional leadership: How successful principals promote teaching and learning: Corwin Press.

Boeije, H. (2002). A purposeful approach to the constant comparative method in the analysis of qualitative interviews. Quality \& Quantity, 36(4), 391-409. https://doi.org/10.1023/A:1020909529486

Bush, T. (2008). From Management to Leadership Semantic or Meaningful Change? Educational $\begin{array}{llll}\text { Management Administration \& Leadership, 36(2), 271-288. } & \end{array}$ https://doi.org/10.1177/1741143207087777

Corbin, J. M., \& Strauss, A. L. (2008). Basics of qualitative research: techniques and procedures for developing grounded theory. Thousand Oaks, Calif.: Sage. https://doi.org/10.4135/9781452230153

Creswell, J. W. (2007). Qualitative inquiry \& research design : choosing among five approaches. Thousand Oaks, Calif.: Sage.

Day, C., Gu, Q., \& Sammons, P. (2016). The Impact of Leadership on Student Outcomes: How Successful School Leaders Use Transformational and Instructional Strategies to Make a Difference. Educational Administration Quarterly. doi:10.1177/0013161x15616863

DuFour, R., \& Marzano, R. J. (2011). Leaders of Learning: How District, School, and Classroom Leaders Improve Student Achievement: ERIC.

Elstad, E. (2009). Schools which are named, shamed and blamed by the media: school accountability in Norway. Educational Assessment Evaluation and Accountability, 21(2), 173-189. doi:10.1007/s11092-009-9076-0

Emstad, A. B. (2011). The principal's role in the post-evaluation process.-How does the principal engage in the work carried out after the schools self-evaluation? Educational Assessment, Evaluation and Accountability, 23(4), 271-288. https://doi.org/10.1007/s11092-011-9128-0

Fullan, M. (2014). The Principal : Three Keys to Maximizing Impact. Hoboken: Wiley.

Furlong, J. (2013). Globalisation, Neoliberalism, and the Reform of Teacher Education in England. The Educational Forum, 77(1), 28-50. doi:10.1080/00131725.2013.739017

Hargreaves, A., \& Fullan, M. (2012). Professional capital : transforming teaching in every school. London: Routledge.

Hitt, D. H., \& Tucker, P. D. (2016). Systematic Review of Key Leader Practices Found to Influence Student Achievement: A Unified Framework. Review of Educational Research, 86(2), 531-569. doi:10.3102/0034654315614911 
Kemmis, S. (2009). Understanding professional practice: a synoptic framework. In B. Green (Ed.), Understanding and Researching Professional Practice (pp. 19-28). Rotterdam: Sense Publishers.

Kemmis, S., \& Grootenboer, P. (2008). Situating praxis in practice: practice architectures and the cultural, social and material conditions for practice. In S. Kemmis \& T. J. Smith (Eds.), Enabling praxis: Challenges for education (pp. 37-62). Rotterdam: Sense Publishers.

Kemmis, S., \& Smith, T. J. (2008). Enabling praxis : challenges for education. Rotterdam: Sense.

Kemmis, S., Wilkinson, J., Edwards-Groves, C., Hardy, I., Grootenboer, P., \& Bristol, L. (2014). Changing practices, changing education: Springer. https://doi.org/10.1007/978-981-4560-47-4

Kemmis, S., Wilkinson, J., Hardy, I., \& Edwards-Groves, C. (2009). Leading and learning: Developing ecologies of educational practice. Paper presented at the Paper at the Symposium "Ecologies of practice" Australian Association for Research in Education., Canberra.

Kunnskapsdepartementet. (2008). Kvalitet i skolen. (St.meld. nr. 31 (2007-2008)). Retrieved from https://www.regieringen.no/no/dokumenter/stmeld-nr-31-2007-2008-/id516853/?ch=1\&q=.

Kvale, S., \& Brinkmann, S. (2009). Det kvalitative forskningsintervju. Oslo: Gyldendal akademisk.

Langfeldt, G. (2015). Skolens kvalitet skapes lokalt : presentasjon av funn fra forskningsprosjektet "Lærende regioner". Bergen: Fagbokforl.

Leithwood, K., Harris, A., \& Hopkins, D. (2008). Seven strong claims about successful school leadership. School Leadership \& Management, 28(1), 27-42. doi:10.1080/13632430701800060

Leithwood, K., Steinbach, R., \& Jantzi, D. (2002). School leadership and teachers' motivation to implement accountability policies. Educational Administration Quarterly, 38(1), 94-119.

Lincoln, Y. S., \& Guba, E. G. (1985). Naturalistic inquiry. Beverly Hills, Calif: Sage.

Møller, J. (2009). Learning to share: a vision of leadership practice. International Journal of Leadership in Education, 12(3), 253-267. https://doi.org/10.1080/13603120802684530

Møller, J., Eggen, A., Fuglestad, O. L., Langfeldt, G., Presthus, A. M., Skrøvset, S., . . Vedøy, G. (2005). Successful school leadership: the Norwegian case. Journal of Educational Administration, 43(6), 584-594. doi:10.1108/09578230510625683

Olson, L. (2008). Lack of School Leadership Seen as a Global Problem; OECD study finds too few candidates at a time when the roles have expanded.(Report). Education Week, 27(33), 8.

Pashiardis, P., Savvides, V., Lytra, E., \& Angelidou, K. (2011). Successful School Leadership in Rural Contexts: The Case of Cyprus. Educational Management Administration \& Leadership, 39(5), 536-553. doi:10.1177/1741143211408449

Patton, M. Q. (2002). Qualitative research \& evaluation methods. Thousand Oaks, Calif.: Sage Publications.

Robinson, V. M. J. (2007). School leadership and student outcomes: Identifying what works and why (Vol. 41): Australian Council for Educational Leaders Winmalee, Victoria, Australia.

Robinson, V. M. J., Lloyd, C. A., \& Rowe, K. J. (2008). The Impact of Leadership on Student Outcomes: An Analysis of the Differential Effects of Leadership Types. Educational Administration Quarterly, 44(5), 635-674. doi:10.1177/0013161x08321509 
Seland, I., Vibe, N., \& Hovdhaugen, E. (2013). Evaluering av nasjonale prøver som system (Vol. 2013/4). Oslo: NIFU.

Spillane, J. P., Halverson, R., \& Diamond, J. B. (2004). Towards a theory of leadership practice: A distributed perspective. Journal of Curriculum Studies, 36(1), 3-34. https://doi.org/10.1080/0022027032000106726

Steyn, G., \& Du Plessis, E. (2007). The implications of the out-of-field phenomenon for effective teaching, quality education and school management. Africa Education Review, 4(2), 144-158. https://doi.org/10.1080/18146620701652754

The Norwegian Directorate of Education and Training. (2016). Ledelse i skolen - krav og forventninger til en rektor. Retrieved from http://www.udir.no/Upload/skoleutvikling/Rektorutdanning/UDIR Ledelse\%20i\%20skolen\%20 BOKMAL web.pdf

Timperley, H. (2011). Knowledge and the Leadership of Learning. Leadership and Policy in Schools, 10(2), 145-170. https://doi.org/10.1080/15700763.2011.557519

Vestheim, O. P. (2014). "Slik blir det til at hele flokken løfter seg. Det er ikke opp til enkeltlærere!" : en kasusstudie av praksis på skoler i områder med lavere utdannings- og inntektsnivå med gode resultater på nasjonale prøver. In A.-L. Østern (Ed.), NAFOL-yearbook 2014 Once a teacher always a teacher. Bergen: Fagbokforl., cop. 2014.

Vestheim, O. P., \& Lyngsnes, K. M. (2016). A study of Norwegian schools achieving good national test results. International Journal of Educational Research, 79, 1-9. doi:10.1016/j.ijer.2016.06.005

Wilkinson, J., \& Kemmis, S. (2015). Practice Theory: Viewing leadership as leading. Educational Philosophy and Theory, 47(4), 342-358. https://doi.org/10.1080/00131857.2014.976928 